\title{
Monitoring of patients on high dose antipsychotic medication
}

\author{
Kate Sillifant, Jacqueline Muir, Mary Crabb and Stephen Read
}

\begin{abstract}
In the light of recently published Royal College of Psychiatrists' guidelines on the use of high dose antipsychotic medication, electrocardiographic and blood investigations were performed on 11 patients with leaming disabillities recelving such treatment. All patients had normal electrocardiograms (ECGs). Four patients had asymptomatic low white cell counts and mild anaemia was detected in three individuals. Three patients were hyponatraemic; liver function tests were essentially normal. lssues around routine monitoring of such patients are discussed.
\end{abstract}

The recently published College consensus statement The Use of High Dose Antipsychotic Medication (Royal College of Psychiatrists, 1993) listed a number of guidelines including: (a) ECGs to exclude long QT interval syndromes, to be repeated every 1-3 months; (b) regular checks on pulse, blood pressure, temperature and the state of hydration to avoid electrolyte imbalance and hypotension, and (c) caution is recommended in those with hepatic or renal impairment.

Patients on such high doses of antipsychotic medication form a heterogeneous group. The learning disabled population on long-term treatment are only mentioned briefly in the statement. There are a number of accepted indications for the use of antipsychotic medication in this group, but this paper does not attempt to address these.

This study aimed to identify the number of patients on high dose antipsychotic drugs in a hospital for adults with learning disability and to carry out a screen of investigations in line with those recommended by the College consensus statement.

\section{The study}

The setting

The study took place in a traditional hospital for learning disabilities in Leeds, which is in the process of contracting, but still houses some 200 individuals awaiting resettlement, including those with multiple and profound disabilities, the more difficult to place 'social care group' and those who have a dual diagnosis, many of whom exhibit challenging behaviour.

\section{The patient group}

Eleven patients were identified from the hospital pharmacy records as being on high dose antipsychotic medication. The patients had all been on antipsychotic medication for a number of years and on their current regime, as listed in Table 1, for at least the last year.

\section{Investigations}

The consensus statement (Royal College of Psychiatrists, 1993) highlights the importance of monitoring for electrolyte imbalance and ECG irregularities. In addition, haematological and liver function abnormalities are recognised sideeffects of antipsychotic medication (British National Formulary, 1995). Thus, ECGs, urea and electrolytes, creatinine, a full blood count and liver function tests were performed. For those receiving depot medication, it was decided to standardise the investigation at one week after the last depot injection.

\section{Table 1. Prescribed medication}

\begin{tabular}{|c|c|c|c|}
\hline $\begin{array}{l}\text { Patient } \\
\text { number }\end{array}$ & Gender & $\begin{array}{l}\text { Haloperidol } \\
\text { depot (mg } \\
\text { per month) }\end{array}$ & $\begin{array}{l}\text { Other psychotropic } \\
\text { medication (all oral) } \\
\text { with dose per doy }\end{array}$ \\
\hline 1 & $\mathbf{F}$ & 700 & risperidone $10 \mathrm{mg}$ \\
\hline $2^{\prime}$ & $M$ & 400 & lamotrigine $50 \mathrm{mg}$ \\
\hline $3^{2}$ & $F$ & 600 & haloperidol $20 \mathrm{mg}$ \\
\hline 4 & $\mathbf{F}$ & 600 & - \\
\hline 5 & $M$ & 700 & zuclopenthixol $60 \mathrm{mg}$ \\
\hline $6^{\prime}$ & $M$ & 840 & - \\
\hline $7^{\prime}$ & $M$ & 600 & - \\
\hline 8 & $M$ & 800 & paroxetine $20 \mathrm{mg}$ \\
\hline $9^{\prime}$ & $F$ & NA & $\begin{array}{l}\text { haloperidol } 70 \mathrm{mg} \\
\text { chlorpromazine } 200 \mathrm{mg}\end{array}$ \\
\hline 10 & $\mathbf{F}$ & NA & $\begin{array}{l}\text { fluphenazine } 10 \mathrm{mg} \\
\text { chlorpromazine } 850 \mathrm{mg}\end{array}$ \\
\hline 11 & $\mathbf{F}$ & NA & $\begin{array}{l}\text { fluphenazine } 15 \mathrm{mg} \\
\text { chlorpromazine } 800 \mathrm{mg}\end{array}$ \\
\hline
\end{tabular}

1. On carbamazepine.

2. Also on ethinyloestradiol with gestodene. 


\section{Findings}

Eleven patients were identified out of a total hospital population of 224 as being on high dose antipsychotic medication and all these patients had normal ECGs.

\section{Biochemical investigations}

Patients 2, 9 and 10 had serum sodium levels of 134, 129 and $132 \mathrm{mmol} / 1$ respectively which fall below the normal laboratory reference range (135-145 mmol/l). Patients 2 and 9 were on carbamazepine, which is a known cause of hyponatraemia (British National Formulary, 1995). All other electrolyte values were within the normal range. Liver function tests were essentially normal with the exception of patient 10 who had an isolated minimally raised bilirubin of $16(3-15 \mu \mathrm{mol} / \mathrm{l})$ and patient 9 who had an isolated raised alkaline phosphatase of 292 (80-280 units).

\section{Haematological investigations}

Patients 1 and 7 had mild hypochromic microcytic anaemia and patient 6 was also slightly anaemic (see Table 2). Subsequent investigations revealed iron deficiency.

Patients 1, 3, 8 and 9 had total white cell counts below the reference range (see Table 3 ). These could be accounted for by reduced neutrophil and/or lymphocyte counts. The relative proportions of white cells were within normal limits.

\section{Comments}

Within this small sample of 11 patients there were no clinically significant abnormal findings. ECGs were all normal. Three patients had asymptomatic low serum sodium levels. Liver function tests were essentially normal. Haematological investigations revealed that three

Table 2. Patients on high dose neuroleptic medication: full blood count results

\begin{tabular}{llllll}
\hline $\begin{array}{l}\text { Patient } \\
\text { number }\end{array}$ & Gender & $\begin{array}{l}\text { Haemoglobin } \\
(\mathbf{g} / \mathrm{dd})\end{array}$ & $\begin{array}{l}\text { Mean cell } \\
\text { volume (ii) }\end{array}$ & $\begin{array}{l}\text { Platelets } \\
\left(\times 10^{9}\right)\end{array}$ & $\begin{array}{l}\text { White cell count } \\
\left(\times 10^{2}\right)\end{array}$ \\
\hline 1 & $\mathrm{~F}$ & 11.0 & 75.0 & 231 & 3.1 \\
$2^{1}$ & $\mathrm{M}$ & 13.6 & 90.0 & 307 & 7.5 \\
3 & $\mathrm{~F}$ & 12.7 & 79.4 & 241 & 3.7 \\
4 & $\mathrm{~F}$ & 12.2 & 84.8 & 294 & 6.1 \\
5 & $\mathrm{M}$ & 14.2 & 85.1 & 156 & 6.5 \\
$6^{1}$ & $\mathrm{M}$ & 12.8 & 81.9 & 243 & 4.8 \\
$7^{1}$ & $\mathrm{M}$ & 12.4 & 77.3 & 326 & 5.3 \\
8 & $\mathrm{M}$ & 13.3 & 88.6 & 201 & 3.4 \\
$9^{\prime}$ & $\mathrm{F}$ & 11.6 & 89.6 & 246 & 3.3 \\
10 & $\mathrm{~F}$ & 13.7 & 92.8 & 288 & 6.8 \\
11 & $\mathrm{~F}$ & 13.9 & 81.7 & 268 & 6.7 \\
Normal & & $\mathrm{M}=13-18$ & $78-98$ & $150-400$ & $4-11$ \\
values $^{2}$ & & $\mathrm{~F}=11.5-16.5$ & & & \\
\hline
\end{tabular}

1. On carbamazepine.

2. Normal values as given by local hospital laboratories.

Table 3. Differential of low white cell count

\begin{tabular}{lllllll}
\hline $\begin{array}{l}\text { Patient } \\
\text { number }\end{array}$ & $\begin{array}{l}\text { White cell } \\
\text { count }\end{array}$ & $\begin{array}{l}\text { Neutrophils } \\
(\%)^{\prime}\end{array}$ & $\begin{array}{l}\text { Lymphocytes } \\
(\%)^{\prime}\end{array}$ & $\begin{array}{l}\text { Monocytes } \\
(\%)^{\prime}\end{array}$ & $\begin{array}{l}\text { Eosinophils } \\
(\%)^{\prime}\end{array}$ & $\begin{array}{l}\text { Basophils } \\
(\%)^{\prime}\end{array}$ \\
\hline Normal & $4-11$ & $2.0-7.5$ & $1.5-4.0$ & $0.2-0.8$ & $0.04-0.4$ & $<0.1$ \\
values & & $(40-75)$ & $(20-45)$ & $(2-10)$ & $(1-6)$ & $(<1.0)$ \\
1 & 3.1 & 1.72 & 1.19 & 0.14 & 0.00 & 0.01 \\
& & $(55.5)$ & $(38.5)$ & $(0.1)$ & $(0.1)$ & $(0.2)$ \\
3 & 3.7 & 1.65 & 1.49 & 0.32 & 0.09 & 0.06 \\
& & $(44.7)$ & $(40.3)$ & $(8.7)$ & $(2.5)$ & $(1.6)$ \\
8 & 3.4 & 2.09 & 0.88 & 0.20 & 0.14 & 0.03 \\
& & $(61.1)$ & $(27.3)$ & $(6.5)$ & $(2.7)$ & $(0.9)$ \\
9 & 3.3 & 1.58 & 1.10 & 0.26 & 0.27 & 0.02 \\
& & $(47.9)$ & $(33.3)$ & $(8.0)$ & $(8.1)$ & $(0.7)$ \\
\hline
\end{tabular}

1. Percentage of all white cells. 
patients had mild asymptomatic anaemia. Four patients had slightly reduced white cell counts but were clinically well, with no evidence of increased susceptibility to infection.

The consensus document addresses the issue of sudden death in patients on high dose antipsychotic medication. This study did not reveal any life threatening abnormalities or indicate that any of the sample were at risk. The patient group were all on long-term high dose antipsychotic agents. A question raised is whether a distinction should be made between patients being treated acutely and those on established regimes (Hirsch \& Barnes, 1994).

Practical difficulties emerged during this study. Two patients required sedation in order to carry out the investigations, and ECG technicians and equipment had to be arranged by contract from another trust.

The list of investigations which was drawn up from the College recommendations and clinical experience would seem to be a reasonable screen for patients on high dose antipsychotic medication. How often should such tests be repeated? Patients in long-term institutional care generally undergo annual physical examinations with appropriate investigations. We would expect that for those on high dose antipsychotic medication, the above blood tests and an ECG would be included. The inference of the consensus statement is that monitoring should be repeated at regular intervals. Is an annual check sufficiently frequent to detect change?

In an attempt to alleviate the anxiety caused by minimally abnormal results, the temptation is to repeat such investigations. This focuses attention on those with clinically insignificant findings and may give false reassurance about those who fall within the normal range. Abnormalities may develop at any time and heightened clinical awareness would seem vital in all patients receiving such medication.

We are left with the question of how often we can reasonably repeat potentially distressing investigations in a group of vulnerable patients who may be unable to give informed consent yet might develop preventable complications.

\section{References}

HIRSCH, S. \& BARNES, T. (1994) Clinical use of high dose neuroleptics. British Journal of Psychiatry, 164, 94-96.

Royal College of Psychiatrists (1993) Consensus Statement on the Use of High Dose Antipsychotic Medication (Council Report CR26). London: Royal College of Psychiatrists.

*Kate Sillifant, Senior Registrar in Child and Adolescent Psychiatry, Unit of Child Mental Health, 12A Clarendon Road, Leeds LS2 9NN: Jacqueline Muir, Senior Registrar in Psychiatry. Northowram Hospital, Halifax, Stephen Read, Senior Lecturer in Psychiatry of Learning Disabilities, Crooked Acres, 1 Spen Lane, Leeds LS5 3EG; and Mary Crabb, Pharmacist, High Royds Hospital, Menston, West Yorkshire LS29 $6 A Q$

*Correspondence 